\title{
PENGARUH PENGETAHUAN DAN PEMAHAMAN PERATURAN PERPAJAKAN, PENGHINDARAN PAJAK DAN SANKSI PERPAJAKAN TERHADAP KEPATUHAN WAJIB PAJAK
}

\author{
(Studi Pada Wajib Pajak Orang Pribadi di Wilayah KPP Pratama Kota Tegal) \\ Davidya Febri ${ }^{1}$ dan Tri Sulistyani ${ }^{2}$ \\ ${ }^{1}$ Program Studi Manajemen Perpajakan dan ${ }^{2}$ Program Studi Akuntansi \\ Fakultas Ekonomi dan Bisnis Universitas Pancasakti
}

\begin{abstract}
The purpose of this study was to determine the effect of knowledge and understanding of taxation regulations, tax avoidance and taxation sanctions simultaneously and partially on taxpayer compliance. To find out the difference in knowledge and understanding of taxation regulations, tax avoidance, taxation and compliance sanctions on private taxpayers of private employees with ASN's personal taxpayers. In this study using the population of all individual taxpayers registered in the Tegal City KPP with a sample of 100 respondents. The sampling technique using simple random sampling. Methods of data collection by distributing questionnaires. The data is processed using SPSS program version 23. The results of this study conclude that the first hypothesis is that there is the influence of knowledge and understanding of tax regulations, tax avoidance and taxation sanctions simultaneously on taxpayer compliance with a significant value of 0,000. The second hypothesis is that there is an influence of knowledge and understanding of taxation regulation partially to taxpayer compliance with the significant value equal to 0,011. The third hypothesis is that there is no partial tax avoidance effect on taxpayer compliance with a significant value of 0.069. The fourth hypothesis is that there is a partial effect of taxation sanctions on taxpayer compliance with a significant value of 0.030. The fifth hypothesis is that there are differences in knowledge and understanding of taxation regulations, tax evasion, tax sanctions and compliance with private taxpayers private employees with taxpayers personal ASN. While for both groups of taxpayers both private and ASN employees do not differ or there is no difference in preferences on tax sanctions.
\end{abstract}

Keywords: knowledge and understanding of taxation regulations, tax avoidance, taxation sanctions and taxpayer compliance.

\section{PENDAHULUAN}

Latar Belakang

Saat ini pajak merupakan
sumber utama dana penerimaan
dalam negeri Indonesia. Sebagian
besar sumber penerimaan negara
yang tertuang dalam Anggaran
Pendapatan dan Belanja Negara
(APBN) berasal dari pajak dan

sekitar $77,6 \%$ rata-rata dari total penerimaan negara bersumber dari penerimaan pajak. Dalam postur APBN 2017 ditetapkan jumlah pendapatan negara sebesar Rp1.750,3 triliun. Jumlah ini terdiri dari penerimaan perpajakan sebesar Rp1.489,9 triliun, Penerimaan Negara Bukan Pajak (PNBP) sebesar Rp250 triliun, dan penerimaan hibah 
sebesar Rp1,4 triliun. Hal ini tentunya masih berpotensi untuk bisa terus ditingkatkan lagi. Mengingat begitu pentingnya peranan pajak, maka pemerintah dalam hal ini Direktorat Jenderal Pajak (DJP) telah melakukan berbagai upaya untuk memaksimalkan penerimaan pajak. Salah satu upaya untuk memaksimalkan penerimaan pajak yaitu dengan diberlakukannya self assesment system yang mengharuskan wajib pajak untuk memenuhi kewajiban perpajakannya yaitu dengan cara mengisi dan menyampaikan Surat Pemberitahuan (SPT) di Kantor Pelayanan Pajak, karena kesadaran dan kepatuhan perpajakan merupakan faktor terpenting dalam pelaksanaan sistem tersebut.

Ketaatan Wajib Pajak dalam melaksanakan ketentuan perpajakan yang berlaku merupakan kepatuhan perpajakan. Wajib Pajak dapat dikatakan patuh apabila Wajib Pajak itu sendiri selalu taat dalam memenuhi kewajibannya untuk membayar pajak yang sesuai dengan ketentuan Peraturan Perundang Undangan perpajakan (Rahayu, 2017:193)

Wajib pajak yang telah memenuhi persyaratan objektif dan subjektif berdasarkan Undang Undang perpajakan wajib mendaftarkan diri untuk memperoleh Nomor Pokok Wajib Pajak (NPWP). Kewajiban bagi setiap wajib pajak yaitu dengan cara memiliki NPWP. Dengan memiliki NPWP maka segala aktifitas yang dilakukan oleh wajib pajak lebih mudah terpantau oleh Direktorat Jenderal Pajak (DJP). Namun dengan adanya kepemilikan NPWP tidak selalu menjamin wajib pajak untuk melakukan kewajibannya yaitu sebagai wajib pajak yang patuh. Karena masih banyak juga wajib pajak yang sudah memiliki NPWP namun tidak melaporkan (Surat Pemberitahuan Tahunan (SPT) (Dessy, 2017).

Salah satu faktor potensial bagi pemerintah untuk meningkatkan kepatuhan wajib pajak dalam memenuhi kewajiban perpajakannya adalah merupakan tingkat pemahaman perpajakan (Syahril, 2013). Menurut Sholichah dalam Syahril (2013) pemahaman wajib pajak terhadap peraturan perpajakan dan undang - undang, dan sikap wajib pajak berpengaruh terhadap perilaku perpajakan wajib pajak, dan akhirnya keberhasilan perpajakan dipengaruhi oleh perilaku perpajakan. Penelitian tentang pengaruh pengetahuan dan pemahaman peraturan perpajakan, penghindaran pajak dan sanksi perpajakan terhadap kepatuhan wajib pajak orang pribadi telah banyak dilakukan oleh peneliti - peneliti sebelumnya.

\section{Perumusan Masalah}

Berdasarkan latar belakang masalah di atas, maka perumusan masalah pada penelitian ini yaitu:

Apakah terdapat pengaruh pengetahuan dan pemahaman peraturan perpajakan, penghindaran pajak dan sanksi perpajakan terhadap kepatuhan wajib pajak orang pribadi?

Apakah terdapat pengaruh pengetahuan dan pemahaman peraturan perpajakan terhadap kepatuhan wajib pajak orang pribadi?

Apakah terdapat pengaruh penghindaran pajak terhadap kepatuhan wajib pajak orang pribadi? 
Apakah terdapat pengaruh sanksi perpajakan terhadap kepatuhan wajib pajak orang pribadi?

Apakah terdapat perbedaan pengetahuan dan pemahaman peraturan perpajakan, penghindaran pajak, sanksi pajak dan kepatuhan pada wajib pajak orang pribadi karyawan swasta dengan wajib pajak orang pribadi ASN?

Tujuan Penelitian

Adapun tujuan dari penelitian ini yaitu:

Untuk mengetahui pengaruh pengetahuan dan pemahaman perpatuhan perpajakan, penghindaran pajak dan sanksi perpajakan terhadap kepatuhan wajib pajak orang pribadi.

Untuk mengetahui pengaruh pengetahuan dan pemahaman perpatuhan perpajakan terhadap kepatuhan wajib pajak orang pribadi.

Untuk mengetahui pengaruh penghindaran pajak terhadap kepatuan wajib pajak orang pribadi.

Untuk mengetahui pengaruh sanksi perpajakan terhadap kepatuhan wajib pajak orang pribadi.

Untuk mengetahui perbedaan pengetahuan dan pemahaman peraturan perpajakan, penghindaran pajak, sanksi pajak dan kepatuhan pada wajib pajak orang pribadi karyawan swasta dengan wajib pajak oang pribadi ASN.

\section{KERANGKA PEMIKIRAN DAN HIPOTESIS}

Pengaruh Pengetahuan dan Pemahaman Peraturan Perpajakan terhadap Kepatuhan Wajib Pajak Orang Pribadi

Pengetahuan pajak adalah proses dimana seorang wajib pajak atau kelompok wajib pajak yang berupaya untuk mengubah tata laku manusia melalui pengajaran dan pelatihan. Masyarakat dapat memperoleh pengetahuan peraturan perpajakan melalui pendidikan baik secara formal maupun tidak formal yang nantinya akan berdampak postif pada kesadaran wajib pajak untuk membayar pajak.

Pemahaman tentang peraturan perpajakan merupakan cara wajib pajak dalam memahami peraturan perpajakan yang telah ditetapkan. Wajib pajak yang paham akan peraturan perpajakan cenderung akan menjadi wajib pajak yang taat dan patuh, karena wajib paham yang benar-benar paham, mereka akan lebih mengetahui akan adanya sanksi administrasi dan sanksi pidana jika melalaikan kewajiban mereka dengan tidak melaporkan SPT dan NPWP. Begitupun sebaliknya, wajib pajak yang tidak dapat memahami peraturan perpajakan maka secara jelas akan cenderung menjadi wajib pajak yang tidak taat atau patuh pada peraturan yang telah ada (Julianti, 2014).

Berdasakan penelitian terdahulu yang sudah dilakukan oleh Syahril (2013), Asbar, dkk (2014), dan Siahaan (2015) menyatakan bahwa pengaruh pengetahuan dan pemahaman peraturan perpajakan berpengaruh positif secara signifikan terhadap kepatuhhan wajib pajak orang pribadi. 
Pengaruh Penghindaran Pajak terhadap Kepatuhan Wajib Pajak Orang Pribadi

Penghindaran pajak umumnya dilakukan oleh wajib pajak karena mempunyai tujuan tertentu yaitu untuk meminimalkan laba operasional perusahaan yang berpengaruh pada jumlah pajak penghasilan terutang perusahaan dengan cara mengurangi penghasilan kena pajak (Rahayu, 2017). Namun penghindaran pajak yang dilakukan oleh seorang wajib pajak ini bukanlah hal yang ilegal dengan catatan selama tidak menyalahi aturan perundang - undangan perpajakan, sehingga mengakibatkan penerimaan kas negara menjadi berkurang karena wajib pajak terus mencari celah untuk mengatur pajaknya tanpa harus melanggar peraturan perpajakan (Hantoyo dkk, 2016)

Berdasarkan penelitian terdahulu yang sudah dilakukan oleh Huda (2014) menyatakan bahwa pengaruh penghindaran pajak berpengaruh secara signifikan terhadap tingkat kepatuhan wajib pajak orang pribadi dalam membayar pajaknya sedangkan menurut Hantoyo (2016) penghindaran pajak tidak berpengaruh secara signifikan terhadap kepatuhan wajib pajak orang pribadi.

Pengaruh Sanksi Perpajakan Terhadap Kepatuhan Wajib Pajak Orang Pribadi

Menurut Mardiasmo (2016: 62) dalam bukunya menyatakan yang dimaksud sanksi perpajakan adalah jaminan ketentuan peraturan perundang - undangan perpajakan (norma perpajakan) akan dipatuhi atau alat untuk mencegah agar wajib pajak tidak melanggar norma perpajakan. Sanksi perpajakan itu sendiri dibedakan menjadi dua, yaitu sanksi administrasi dan sanksi pidana.

Berdasarkan penelitian yang telah dilakukan oleh Saragih (2014) dan Hantoyo (2016) menunjukan bahwa pengaruh sanksi perpajakan berpengaruh secara signifikan terhadap kepatuhan wajib pajak orang pribadi dalam membayar pajak.

Preferensi Kepatuhan Pajak Pada WPOP Karyawan Swasta dan WPOP ASN

Preferensi kepatuhan pajak merupakan salah satu karakteristik dimana seorang wajib pajak bersifat patuh atau tidak terhadap kewajibannya sebagai wajib pajak.

Dalam penelitian ini akan menguji apakah terdapat perbedaan kecenderungan untuk berperilaku patuh terhadap pelaporan pajak yang dilakukan oleh WPOP Karyawan Swasta dengan WPOP ASN dalam melaporkan kewajibannya untuk membayar pajak.

H1: Terdapat pengaruh pengetahuan dan pemahaman peraturan perpajakan, penghindaran pajak dan sanksi perpajakan secara simultan terhadap kepatuhan wajib pajak orang pribadi.

H2: Terdapat pengaruh pengetahuan dan pemahaman peraturan perpajakan secara parsial terhadap kepatuhan wajib pajak orang pribadi.

H3: Terdapat pengaruh penghindaran pajak secara parsial terhadap kepatuhan wajib pajak orang pribadi.

H4: Terdapat pengaruh sanksi perpajakan secara parsial terhadap kepatuhan wajib pajak orang pribadi. 
H5: Terdapat perbedaan pengetahuan dan pemahaman peraturan perpajakan, penghindaran pajak, sanksi pajak dan kepatuhan pada wajib pajak orang pribadi karyawan swasta dengan wajib pajak orang pribadi ASN.

\section{METODE PENELITIAN}

Pengumpulan Data

Dalam penelitian ini menggunakan metode kuantitatif yang teknik pengumpulan datanya dengan cara mengedarkan kuesioner ke tempat-tempat yang akan diteliti, mengenai kepatuhan pajak pada WPOP. Lokasi penelitian ini yaitu dibeberapa kantor swasta dan kantor pemerintahan yang ada di Kota Tegal.

Definisi Operasional Variabel

Tabel 1 Operasional Variabel

\begin{tabular}{|c|c|c|c|}
\hline Variabel & Definisi & Indikator & $\begin{array}{c}\text { Skala } \\
\text { Pengukuran }\end{array}$ \\
\hline $\begin{array}{l}\text { Kepatuhan Wajib } \\
\text { Pajak (Y) } \\
\text { (Kusuma, 2016) }\end{array}$ & $\begin{array}{l}\text { Kepatuhan wajib pajak } \\
\text { merupakan keadaan dimana } \\
\text { wajib pajak memenuhi } \\
\text { semua kewajiban } \\
\text { perpajakan dan } \\
\text { melaksanakan hak } \\
\text { perpajakannya. }\end{array}$ & $\begin{array}{l}\text { 1. Mendaftarkan NPWP atas } \\
\text { kemauan sendiri } \\
\text { 2. Wajib pajak harus mendaftarkan } \\
\text { diri untuk NPWP } \\
\text { 3. Mengisi SPT sesuai dengan } \\
\text { ketentuan perundang-undangan } \\
\text { 4. Mengetahui batas akhir dalam } \\
\text { pelaporan pajak } \\
\text { 5. Teknologi informasi } \\
\text { mempermudah pelaporan SPT } \\
\text { 6. Tepat waktu dalam membayar } \\
\text { pajak } \\
\text { 7. Membayar kewajiban pajak serta } \\
\text { tunggakan pajaknya }\end{array}$ & Interval \\
\hline $\begin{array}{l}\text { Pengetahuan } \\
\text { dan Pemahaman } \\
\text { Peraturan } \\
\text { Perpajakan } \\
\text { (X1) (Badan } \\
\text { Pengelola } \\
\text { Pendapatan Daerah } \\
\text { Jawa Tengah) }\end{array}$ & $\begin{array}{l}\text { Pengetahuan dan } \\
\text { Pemahaman Peraturan } \\
\text { Perpajakan merupakan } \\
\text { proses dimana wajib pajak } \\
\text { mengetahui tentang } \\
\text { perpajakan dan } \\
\text { mengaplikasikan } \\
\text { pengetahuan itu untuk } \\
\text { membayar pajak. }\end{array}$ & $\begin{array}{l}\text { 1. Mengetahui apabila memiliki } \\
\text { penghasilan maka berkewajiban } \\
\text { untuk membayar pajak penghasilan } \\
\text { 2. Tidak tahu tentang adanya sanksi } \\
\text { ketika tidak membayar pajak } \\
\text { penghasilan } \\
\text { 3. Mengetahui bahwa pajak } \\
\text { penghasilan merupakan sumber } \\
\text { penerimaan negara terbesar } \\
\text { 4. Mengetahui informasi pajak } \\
\text { penghasilan melalui baliho } \\
\text { 5. Tidak mengetahui dimana tempat } \\
\text { untuk melaporkan SPT } \\
\text { 6. Tidak mengetahui kapan harus } \\
\text { lapor SPT } \\
\text { 7. Paham apa saja bentuk sanksi jika } \\
\text { tidak membayar pajak penghasilan }\end{array}$ & Interval \\
\hline
\end{tabular}




\begin{tabular}{|c|c|c|c|}
\hline $\begin{array}{l}\text { Penghindaran } \\
\text { Pajak (X2) } \\
\text { (Lestari, 2015 dan } \\
\text { Sari 2015) }\end{array}$ & $\begin{array}{l}\text { Penghindaran pajak } \\
\text { merupakan tindakan legal } \\
\text { yang dilakukan oleh wajib } \\
\text { pajak untuk mengurangi } \\
\text { laba operasional } \\
\text { perusahaan. }\end{array}$ & $\begin{array}{l}\text { 1.Penghindaran pajak merupakan } \\
\text { suatu usaha pengurangan secara } \\
\text { legal dengan cara memanfaatkan } \\
\text { ketentuan - ketentuan dibidang } \\
\text { perpajakan seara optimal } \\
\text { 2. Menyetorkan pajak tidak sesuai } \\
\text { dengan objek pajak yang dimiliki } \\
\text { 3. Menempatkan dan mencatat dana } \\
\text { modal sebagai pinjaman, sehingga } \\
\text { pengeluaran yang seharusnya } \\
\text { merupakan pembayaran deviden } \\
\text { bisa dinyatakan sebagai } \\
\text { pengeluaran berupa bunga } \\
\text { 4.Penghitungan gaji karyawan } \\
\text { dilakukan dengan benar } \\
\text { 5.Penghindaran pajak digunakan } \\
\text { wajib pajak untuk memanfaatkan } \\
\text { celah pajak agar membayarkan } \\
\text { utang pajaknya dengan jumlah } \\
\text { yang lebih rendah }\end{array}$ & Interval \\
\hline $\begin{array}{l}\text { Sanksi } \\
\text { Perpajakan (X3) } \\
\text { (Sutiyono, } \\
\text { 2013) }\end{array}$ & $\begin{array}{l}\text { Sanksi perpajakan } \\
\text { merupakan hukuman } \\
\text { yang diberikan kepada } \\
\text { wajib pajak yang tidak } \\
\text { memenuhi kewajibannya. }\end{array}$ & $\begin{array}{l}\text { 1. Sanksi pidana yang dikenakan bagi } \\
\text { pelanggar aturan pajak cukup berat } \\
\text { 2. Sanksi administrasi yang } \\
\text { dikenakan bagi pelanggar aturan } \\
\text { pajak ringan } \\
\text { 3. Pengenaan sanksi yang cukup berat } \\
\text { merupakan salah satu sarana untuk } \\
\text { mendidik wajib pajak } \\
\text { 4. Sanksi pajak harus dikenakan } \\
\text { tanpa toleransi } \\
\text { 5. Pengenaan sanksi atas pelanggaran } \\
\text { pajak dapat dinegoisasi } \\
\text { 6. Sanksi denda merupakan hal } \\
\text { penting agar tercipta kedisiplinan } \\
\text { dan kepatuhan perpajakan } \\
\text { 7.Pengenaan sanksi dilaksanakan } \\
\text { dengan tegas kepada wajib pajak } \\
\text { atas pelanggaran yang dilakukan }\end{array}$ & Interval \\
\hline $\begin{array}{l}\text { Kelompok } \\
\text { WPOP }\end{array}$ & $\begin{array}{l}\text { Membagi WPOP } \\
\text { menjadi } 2 \text { kelompok }\end{array}$ & $\begin{array}{l}0 \text { Untuk karyawan Swasta } \\
1 \text { Untuk ASN }\end{array}$ & Nominal \\
\hline
\end{tabular}

\section{HASIL PENELITIAN}

Uji Validitas

Berdasarkan uji validitas dapat diketahui bahwa pengujian instrumen pada konstruk variabel pengetahuan dan pemahaman peraturan perpajakan (X1), penghindaran pajak (X2), sanksi perpajakan (X3) dan kepatuhan wajib pajak (Y) dinyatakan valid karena nilai signifikansi $<0,05$.
Uji Reliabilitas

Uji reliabel pada masing masing variabel memiliki nilai Cronbach Alpha > 0,60 yaitu pada variabel pengetahuan dan pemahaman peraturan perpajakan sebesar 0,732 , penghindaran pajak sebesar 0,630, sanksi perpajakan sebesar 0,633, dan kepatuhan wajib pajak sebesar 0,766. Berdasarkan uji reliabel tersebut, maka dapat disimpulkan bahwa pengetahuan 
dan pemahaman peratuan perpajakan, penghindaran pajak, sanksi perpajakan dan kepatuhan wajib pajak adalah reliable.

Regresi Linear Berganda

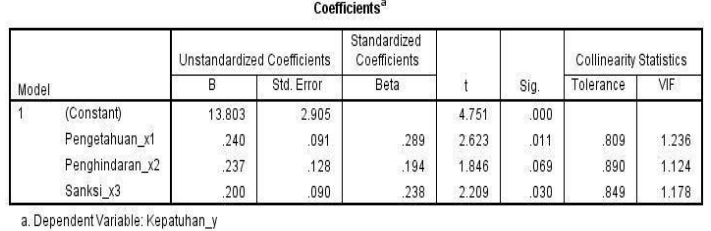

Berdasarkan tabel diatas, maka didapatkan model persamaan regresi seperti berikut:

$$
\mathrm{Y}=13,803+0,240 \mathrm{X}_{1}+0,237 \mathrm{X}_{2}+0,200 \mathrm{X}_{3}+\mathrm{e}
$$

\section{Uji Statistik F}

Uji $\mathrm{F}$ menguji joint hipotesis bahwa b1, b2 dan b3 secara simultan sama dengan nol. Uji hipotesis ini dinamakan uji signifikansi secara keseluruhan terhadap garis regresi yang diobservasi maupun estimasi, apakah Y berhubungan linear terhhadap X1, X2 dan X3 (Ghozali, 2016:96). Berikut adalah hasil dari uji $\mathrm{F}$ :

ANOVA $^{\mathrm{a}}$

\begin{tabular}{|c|c|c|c|c|c|c|}
\hline Mode & & $\begin{array}{l}\text { Sum of } \\
\text { Squares }\end{array}$ & df & Mean Square & $\mathrm{F}$ & Sig. \\
\hline \multirow[t]{3}{*}{1} & Regression & 142.270 & 3 & 47.423 & 9.639 & $.000^{\mathrm{b}}$ \\
\hline & Residual & 359.158 & 73 & 4.920 & & \\
\hline & Total & 501.429 & 76 & & & \\
\hline
\end{tabular}

Berdasarkan tabel diatas hipotesis pertama dari uji statistik $\mathrm{F}$, menyatakan bahwa semua variabel yang digunakan dalam penelitian ini yaitu pengetahuan dan pemahaman, penghindaran pajak dan sanksi perpajakan berpengaruh terhadap kepatuhan wajib pajak. Hal ini dapat dilihat dari nilai signifikan yang diperoleh sebesar $0,000(0,000<0,05)$ dengan nilai $F_{\text {hitung }}$ yang dihasilkan sebesar 9,639 nilai ini lebih besar dari nilai $F_{\text {tabel }}$ yaitu sebesar 2,73 (9,639> 2,73)
Uji Statistik t

Uji statistik t tujuannya untuk menunjukkan bahwa seberapa jauh pengaruh satu variabel bebas atau independen secara individu dalam menjelaskan variasi variabel dependennya (Ghozali, 2016:97).

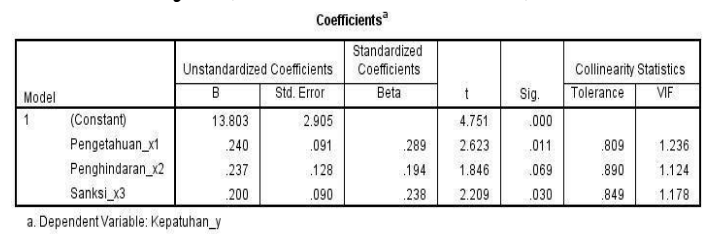

Berdasarkan tabel diatas, diketahui bahwa pengaruh variabel - variabel independen terhadap variabel dependen yaitu sebagai berikut:

Hipotesis kedua: berdasarkan hasil perhitungan uji $\mathrm{t}$ bahwa hasil koefisien regresi untuk variabel pengetahuan dan pemahaman peraturan perpajakan mencapai nilai signifikan sebesar 0,011 (0,011 < 0,05) karena signifikansi tidak melebihi tingkat signifikan maka variabel pengetahuan dan pemahaman peraturan perpajakan dapat dikatakan berpengaruh positif terhadap kepatuhan wajib pajak.

Hipotesis ketiga: berdasarkan hasil perhitungan uji $\mathrm{t}$ bahwa hasil koefisien regresi untuk variabel penghindaran pajak mencapai nilai signifikan sebesar 0,069 karena signifikansi melebihi tingkat signifikan yaitu $(0,069>0,05)$ maka variabel penghindaran pajak dapat dikatakan tidak berpengaruh berpengaruh terhadap kepatuhan wajib pajak.

Hipotesis keempat: berdasarkan hasil perhitungan uji $\mathrm{t}$ bahwa hasil koefisien regresi untuk variabel sanksi perpajakan mencapai nilai signifikan sebesar $0,030 \quad(0,030<$ $0,05)$ karena signifikansi tidak melebihi tingkat signifikan maka variabel sanksi perpajakan dapat 
dikatakan berpengaruh positif terhadap kepatuhan wajib pajak.

Koefisien Determinasi $\left(\mathrm{R}^{2}\right)$

Koefisien Determinan $\left(\mathrm{R}^{2}\right)$ tujuannya untuk mengukur seberapa jauh kemampuan model untuk dapat menjelaskan variasi variabel terikat (dependen). Nilai dari koefisien determinasi itu sendiri yaitu antara nol dan satu. Apabila nilai lebih kecil itu berarti kemampuan variabel-variabel independen dalam menjelaskan variasi variabel dependen sangat terbatas. Nilai yang lebih mendekati satu bararti variabel- variabel independen memberikan hampir semua dari informasi yang dibutuhkan untuk memprediksi apa saja variasi variabel dependen (Ghozali, 2016:95). Berikut ini merupakan tabel dari hasil uji Koefisien Determinasi $\left(\mathrm{R}^{2}\right)$ :

\begin{tabular}{|c|c|c|c|c|}
\hline \multicolumn{5}{|c|}{ Model Summary } \\
\hline Model & $\mathrm{R}$ & R Square & $\begin{array}{c}\text { Adjusted R } \\
\text { Square }\end{array}$ & $\begin{array}{l}\text { Std. Error of } \\
\text { the Estimate }\end{array}$ \\
\hline 1 & $.533^{\mathrm{a}}$ & .284 & .254 & 2.218 \\
\hline
\end{tabular}

Berdasarkan tabel diatas, hasil dari uji koefisien determinasi pada Adjusted R Square (Adjusted $\mathrm{R}^{2}$ ) dapat dilihat bahwa nilainya adalah 0,254 atau 25,4\%. Hal ini menunjukkan bahwa variabel independen yaitu pengetahuan, penghindaran pajak dan sanksi perpajakan dapat menjelaskan variabel dependen yaitu kepatuhan wajib pajak sebesar 0,254 atau $25,4 \%$. Sedangkan sisanya yaitu $74,6 \%$ yang dijelaskan oleh variabel lainnya yang tidak digunakan dalam penelitian ini.
Uji Beda Independent $\mathrm{t}$ - test

Uji beda $\mathrm{t}$ - test gunanya untuk menentukan apakah dua sampel yang saling tidak berhubungan ini memiliki nilai ratarata yang berbeda. Uji beda $\mathrm{t}$ - test itu sendiri dapat dilakukan dengan cara membandingkan perbedaan antara dua sampel atau dengan cara lain yaitu menggunakan rumus seperti yang dapat ditulis sebagai berikut (Ghozali, 2016:64). Berikut ini adalah hasil dari pengujian Uji Beda Independent $\mathrm{t}$ - test:

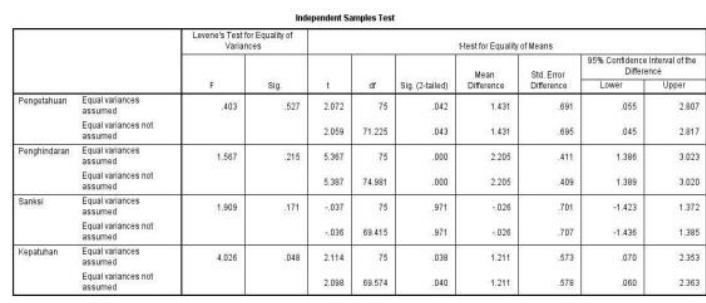

Berdasarkan tabel diatas dapat dilihat bahwa:

Preferensi variabel pengetahuan menunjukkan bahwa terdapat perbedaan antara karyawan swasta dan ASN sebesar 0,043 $(0,043<0,05)$. Preferensi variabel penghindaran pajak menunjukan bahwa terdapat perbedaan antara karyawan swasta dan ASN sebesar 0,000 $(0,000<$ $0,05)$. Preferensi variabel sanksi perpajakan menunjukan bahwa tidak terdapat perbedaan antara karyawan swasta dan ASN sebesar 0,971 $(0,971>0,05)$. Preferensi variabel kepatuhan menunjukan bahwa terdapat perbedaan antara karyawan swasta dan ASN sebesar 0,040 $(0,040<0,05)$.

\section{KESIMPULAN DAN SARAN}

Kesimpulan

Berdasarkan data yang telah diolah dengan menggunakan model 
analisis regresi linear berganda, maka dapat disimpulkan bahwa:

Pengetahuan dan pemahaman peraturan perpajakan, penghindaran pajak dan sanksi perpajakan secara simultan berpengaruh positif signifikan terhadap kepatuhan wajib pajak.

Pengetahuan dan pemahaman peraturan perpajakan secara parsial berpengaruh positif terhadap kepatuhan wajib pajak.

Penghindaran pajak secara parsial berpengaruh negatif atau dapat dikatakan tidak berpengaruh terhadap kepatuhan wajib pajak.

Sanksi perpajakan secara parsial berpengaruh positif terhadap kepatuhan wajib pajak.

Terdapat perbedaan pengetahuan dan pemahaman peraturan perpajakan, penghindaran pajak, sanksi perpajakan dan kepatuhan pada wajib pajak orang pribadi karyawan swasta dengan wajib pajak orang pribadi ASN. Sementara kedua kelompok wajib pajak tersebut baik karyawan swasta maupun ASN tidak berbeda atau tidak terdapat perbedaan preferensi pada sanksi perpajakan.

Saran

Berdasarkan pembahasan dan kesimpulan, maka penulis menyarankan bahwa:

Pengetahuan dan pemahaman peraturan perpajakan, penghindaran pajak dan sanksi perpajakan secara simultan berpengaruh positif signifikan terhadap kepatuhan wajib pajak. Dalam hal ini, peneliti menyarankan bahwa untuk aparat perpajakan agar lebih banyak memberikan informasi berupa sosialisasi tentang perpajakan baik secara formal maupun non forma kepada wajib pajak agar wajib pajak dapat lebih mengetahui dan memahami tentang adanya peraturan perpajakan sehingga tindakan untuk melakukan penghindaran pajak dapat berkurang dan perlu diterapkannya sanksi yang pasti agar wajib pajak menjadi patuh dalam pelaporan perpajakannya dan juga agar penerimaan negara setiap tahunnya dapat bertambah.

Pengetahuan dan pemahaman peraturan perpajakan secara parsial berpengaruh positif terhadap kepatuhan wajib pajak. Dalam hal ini, peneliti menyarankan untuk memperbanyak sosialisasi tentang perpajakan baik secara langsung maupun tidak langsung agar wajib pajak menjadi tahu dan lebih memahami akan peraturan perpajakan sehingga tercipta wajib pajak yang patuh.

Penghindaran pajak secara parsial berpengaruh negatif atau dapat dikatakan tidak berpengaruh terhadap kepatuhan wajib pajak. Dalam hal ini, peneliti menyarankan bahwa untuk aparat perpajakan agar lebih disiplin dalam hal pengecekan jumlah pajak yang dilaporkan wajib pajak, apakah sudah sesuai dengan perhitungannya atau belum agar tidak terjadi tindakan penghindaran pajak meskipun tindakan kecurangan seperti penghindaran pajak termasuk hal yang bukan illegal.

Sanksi perpajakan secara parsial berpengaruh positif terhadap kepatuhan wajib pajak. Dalam hal ini, peneliti menyarankan 
bahwa sanksi perpajakan seharusnya dilakukan secara tegas dan tidak membeda bedakan kepada wajib pajak yang lalai atau tidak patuh akan pelaporan pajaknya agar tercipta kedisiplinan dalam pelaporan pajak sehingga penerimaan pajak setiap tahunnya dapat terus meningkat.

Terdapat perbedaan pengetahuan dan pemahaman peraturan perpajakan, penghindaran pajak, sanksi perpajakan dan kepatuhan pada wajib pajak orang pribadi karyawan swasta dengan wajib pajak orang pribadi ASN. Sementara kedua kelompok wajib pajak tersebut baik karyawan swasta maupun ASN tidak berbeda atau tidak terdapat perbedaan preferensi pada sanksi perpajakan. Dalam hal ini, peneliti menyarankan bahwa perlu diadakannya sosialisasi tentang perpajakan secara menyeluruh kepada wajib pajak baik karyawan swasta atau ASN agar tidak terdapat perbedaan preferensi tentang perpajakan.

\section{DAFTAR PUSTAKA}

Asbar Akromi Khairina, Ruhul Fitros, dan Rusli. (2014). "Pengaruh Tingkat Kepuasan Pelayanan, Pemahaman Perpajakan, Keadilan Perpajakan, Sanksi Perpajakan Dan Kesadaran Perpajakan Terhadap Tingkat Kepatuhan Wajib Pajak Orang Pribadi Pada KPP Pratama Senapelan Pekanbaru". Vol 1, No 2 (2014).

Dessy. (2017). “Analisis Faktor - Faktor Yang Mempengaruhi Kepatuhan Wajib Pajak Orang Pribadi (Studi Kasus di KPP Pratama Kalideres)”.

Ghozali, imam. (2016). Aplikasi Analisis Multivariete dengan Program IBM SPSS 23. Semarang: Badan Penerbit Universitas Diponegoro.

Hantoyo Shinung Sakti, Kertahadi, dan Siti Ragil Handayani. (2016). "Pengaruh Penghindaran Pajak Dan Sanksi Perpajakan Terhadap Kepatuhan Wajib Pajak (Studi Pada Wajib Pajak di Kantor Pelayanan Pajak Pratama Tegal)". Jurnal Perpajakan, Vol 9, No 1 (2016).

Hidayat, Nurdin dan Dedi Purwana. (2017). Perpajakan Teori \& Praktik. Jakarta: PT. Raja Grafindo Persada.

https://bisnis.tempo.co/read/867110/djp-sebut-baru-5897-persen-wajib-pajak-lapor-spt

https://www.kemenkeu.go.id/apbn2017

Huda, Fachrizal. (2014). "Pengaruh Penghindaran Pajak Dan Penggelapan Pajak Teradap Kepatuhan Wajib Pajak Orang Pribadi Pada KPP Pratama Bekasi Utara". 
Julianti, Murni. (2014). "Analisis Faktor - Faktor Yang Mempengaruhi Kepatuhan Wajib Pajak Orang Pribadi Untuk Membayar Pajak Dengan Kondisi Keuangan Dan Preferensi Risiko Wajib Pajak Sebagai Variabel Moderating (Studi Kasus Pada Wajib Pajak Yang Terdaftar Di KPP Pratama Candisari Semarang)".

Kusuma, Kartika Candra. (2016). "Pengaruh Kualitas Pelayanan Pajak, Pemahaman Peraturan Perpajakan Serta Sanksi Perpajakan Terhadap Kepatuhan Wajib Pajak Orang Pribadi dalam Membayar Pajak Tahun 2014 (Studi Kasus pada Wajib Pajak yang Terdaftar di Kantor Pelayanan Penyuluhan dan Konsultasi Perpajakan Wonosobo)".

Lestari, Wahyu. (2015). "Pengaruh Keadilan, Administrasi Perpajakan, Serta Pengetahuan dan Pemahaman Wajib Pajak Terhadap Tax Avoidance (Studi Kasus pada KPP Pratama Semarang Candisari)”.

Mardiasmo. (2016). Perpajakan Edisi Terbaru. Yogyakarta: CV. Andi Offset.

Nugraheni, Agustina Dewi. (2015). "Faktor - Faktor Yang Mempengaruhi Kepatuhan Wajib Pajak Orang Pribadi (Studi Empiris Pada Wajib Pajak di Kota Magelang”.

Rahayu, Siti Kurnia. (2017). Perpajakan Konsep dan Aspek Formal. Bandung: Rekayasa Sains.

Republik Indonesia. 2009. Undang-Undang No. 16 Tahun 2009 tentang penetapan peraturan pemerintah.

Republik Indonesia. 2007. Undang - Undang No. 28 Tahun 2007 tentang ketentuan umum dan tata cara perpajakan.

Santoso, Singgih. (2015). Menguasai Statistik Parametrik Konsep dan Aplikasi dengan SPSS. Jakarta: PT Elex Media Komputindo.

Saragih, Fitriani. (2014). "Pengaruh Kesadaran Wajib Pajak, Pemahaman Peraturan Perpajakan Dan Sanksi Pajak Terhadap Kepatuhan Wajib Pajak Orang Pribadi (Pada KPP Pratama Medan Kota)".

Sari, Trias Maya. (2015). "Pengaruh Keadilan, Self Assesment System, Diskriminasi, Pemahaman Perpajakan, Pelayanan Aparat Pajak, dan Kemungkinan Terdeteksi Kecurangan terhadap Tindakan Tax Evasion (Studi Kasus pada KPP Pratama Semarang Candisari)".

Siahaan, Maslyn Eva. (2015). "Pengaruh Persepsi Pelaksanaan Sensus Pajak Nasional, Pengetahuan Dan Pemahaman Peraturan Perpajakan, Dan Kesadaran Perpajakan Terhadap Kepatuhan Wajib Pajak Orang Pribadi (WPOP) Pada KPP Pratama PekanBaru Senapelan". Vol 2, No 2 (2015).

Sugiyono. (2012). Metode Penelitian Bisnis (Pendekatan Kuantitatif, Kualitatif, dan $R \& D)$. Bandung: CV Alfabeta. 
Sutiyono, Agus Eko. (2013). “Analisis Faktor-Faktor yang Mempengaruhi Kepatuhan Formal Wajib Pajak Orang Pribadi (Studi Kasus pada KPP Pratama Blitar)".

Syahril, Farid. (2013). "Pengaruh Tingkat Pemahaman Wajib Pajak Dan Kualitas Pelayanan Fiskus Terhadap Tingkat Kepatuhan Wajib Pajak PPh Orang Pribadi (Studi Empiris Pada KPP Pratama Kota Solok)" 